\title{
MECHATRONIC EDUCATION AT THE FACULTY OF TECHNICAL SCIENCES NOVI SAD
}

\author{
Gordana Ostojic, Vukica Jovanovic, Drazan Kozak, Zeljko Ivandic, Stevan Stankovski
}

Subject review

The emerging engineering field of mechatronics has caught the attention of many engineering professionals, academics and government officials in recent years, nationally and globally. The main reason for this is that many modern products are no longer purely electrical and electronic or mechanical. Moreover, they are integrated multidisciplinary products which are made from subsystems which require engineering knowledge of different disciplines. Hence, increasing number of universities is offering courses, certificates and programs at undergraduate and graduate levels in the area of mechatronics. This paper presents an educational program in mechatronics at the Faculty of Technical Sciences, University of Novi Sad, Serbia. In addition, student evaluation of the mechatronics program is presented. The conducted survey enabled faculty to gain more insight into student opinions about this program which provided valuable feedback for further program improvements.

Keywords: engineering education; mechatronics; study programs

Edukacija u polju mehatronike na Fakultetu tehničkih znanosti u Novom Sadu

Pregledni članak

Nastajanje inženjerskog polja mehatronike privlači pozornost mnogih tehničkih stručnjaka, akademika i vladinih dužnosnika u posljednjih nekoliko godina, na nacionalnoj i globalnoj razini. Glavni razlog za to je da mnogi suvremeni proizvodi više nisu čisto električni i elektronski ili mehanički. Štoviše, oni su integrirani multidisciplinarni proizvodi koji su izrađeni od podsustava koji zahtijevaju inženjersko znanje iz različitih disciplina. Tako sve veći broj sveučilišta nude tečajeve, certifikate i programe na preddiplomskoj i diplomskoj razini u području mehatronike. Ovaj članak predstavlja obrazovni program mehatronike na Fakultetu tehničkih znanosti Sveučilišta u Novom Sadu u Srbiji. Osim toga, u članku je prikazana procjena studenata programa mehatronike. Provedeno istraživanje omogućilo je bolji uvid u mišljenje studenata o ovom programu, a samim tim i vrijedne povratne informacije koje će omogućiti daljnja poboljšanja programa.

Ključne riječi: inženjersko obrazovanje; mehatronika; studijski programi

\section{Introduction}

The term mechatronics became a widely used name for a multidisciplinary engineering area [1]. Industrial applications are more complex so there is apparent need for engineers who would be able to grasp a multidisciplinary nature of many projects which involve synergy [2] among the mechanical systems, control systems, electronic systems, and computers [3, 4]. Mechatronic systems can be found in many modern products such as high end printers, washing machines, coffee makers, vehicles, airplanes, medical equipment, machine tools etc. $[5 \div 7]$. New approach to engineering has been developed to provide the industry with a new set of engineers who would be able to design in a multidisciplinary environment [8].

Modern products have become increasingly complex because they include various sub systems designed by engineers from different disciplines [5, 9]. One of the biggest challenges which is facing any kind of engineering course of programs in mechatronic engineering is that it is generally believed that novice engineering student would not be able to tackle complex engineering problems in the area of mechatronics [10].

Radical advances in actuators and sensors, power electronics, solid-state devices, materials and packaging, computers and information technology, microprocessors, digital signal and optical processing, computer-aideddesign tools and simulation software have led to many new challenges to the academia and industry [11]. For that reason, many universities are introducing mechatronics concepts in their programs for their students to master the complexity of modern manufacturing systems [12].
One of the first courses in Mechatronics Engineering at Mechanical Engineering department was run at the Toyohashi University in Japan since 1983 [13], and in Europe the first courses were introduced in the middle eighties [14]. Mechatronic course was introduced at postgraduate level in the United Kingdom in mid-eighties, and in 1988 at undergraduate level [15]. This paper presents an educational program in mechatronics at the Faculty of Technical Sciences, University of Novi Sad, Serbia.

\section{Mechatronic engineering program at the Faculty of Technical Sciences}

Faculty of Technical Sciences - FTN (equivalent to College of Engineering in the U.S.) at the University of Novi Sad was established in 1960. Educational and scientific field of the Faculty of Engineering is an interdisciplinary technical and technological science which is organized at the following levels of study: Undergraduate Academic Studies of 8 semesters (4 years) with 240 ECTS; Undergraduate Professional Studies of 6 semesters (3 years) with 180 ECTS; Master Academic Studies of $2 \div 4$ semesters ( 2 years) with 120 ECTS; Specialist Academic Studies of $2 \div 4$ semesters $(1,5$ years) with 90 ECTS, Specialist Professional Studies of 2 $\div 4$ semesters (2 years) with 120 ECTS and Doctoral Academic Studies of 6 semesters (3 years) with 180 ECTS.

One academic year matches 60 ECTS-credits with one credit for each $25 \div 30$ hours of work [16]. ECTS are obtained or the total student engagement related to active teaching (lectures, exercises, seminars, colloquiums, exams, and thesis), field work, professional training and 
individual work, such as studying in the library or at home. ECTS are gained in the classroom activities that are designed for each course, but they are accepted only after the student passes the course exam. Points earned for each course are included in the amount of credits needed to complete each year or a level of studies (first level undergraduate studies degree; second level - master studies or specialized academic or professional studies; third level - doctoral studies).

There are 88 programs of study for all levels of study at FTN. Twenty six are programs of undergraduate academic study, three are programs of undergraduate professional studies, 33 master academic programs studies, 7 are specialized academic study, 3 are specialized professional studies programs and 16 doctoral engineering areas.

The FTN is the only college in the Republic of Serbia in which the Mechatronic study program is implemented at all three levels of study: undergraduate, master and doctoral. Undergraduate academic study program Mechatronic is the first interdisciplinary study program at the FTN. This study program was first time implemented in 2002. Academic name that students acquire after finishing the study is Engineer of Mechatronics. All three levels of mechatronic education are at the Department of Industrial Engineering and Management, which serves as a main department for this study program. In addition, courses are taught by faculty from the following departments: Department of Power, Electronic and Telecommunication Engineering, Department of Computing and Control Engineering, Department of Mechanization and Design Engineering, Department of Technical Mechanics, Department of Fundamental Science, Department of Environment Engineering and Safety at Work and Department of Production Engineering.

Various universities all over the world offer mechatronics courses or have mechatronics research laboratories. At some universities, mechatronics can be an area of specialization for students from different departments such as mechanical engineering, electrical engineering and computer engineering, including courses thought by a faculty from these departments as senior electives [17]. At the same time, some other universities offer undergraduate studies in mechatronics as a three, four or five yearlong programs resulting in degrees such as Bachelor of Science or Bachelor of Engineering. Different engineering programs have different number of credits devoted to social science and elective courses. Some programs such as European engineering programs have smaller ratio of social sciences and humanities in their program. Usually, they will only include a foreign language, sociology, engineering economics which is far less than a typical U.S. engineering program might offer. In addition, different mechatronics education programs include different ratios of courses related to different areas which fall into the multidisciplinary area of mechatronics. Some departments were founded as initiatives of faculty from Mechanical Engineering, some from faculty from Electrical and Computer Engineering, some from engineering and other from engineering technology and that influences the nature of the number of courses related to basic mechatronics disciplines that lead to the emerging and development of mechatronics engineering area (mechanical engineering, electrical engineering, computer engineering and computer science). This might be related to the main emphasis of mechatronic program. In addition to that, the nature of focus of research labs, the nature of graduate program focus and faculty expertise at these institutions also has an impact to the nature of programs in mechatronics engineering.

Mechatronics education around the world has various levels such as: course level, education at the vocational high schools (predominantly in Europe and Asia), mechatronics certificates, Associate of Applied Science degree, Bachelor of Science (U.S., Australia and U.K.) or Bachelor of Engineering (Europe and Asia), Master of Science degree or doctoral studies.

- Europe: Many European universities offer different levels of mechatronic education. Undergraduate mechatronics education can last 3 or 4 years. Some universities offer two different levels, Bachelor of Engineering (4 years) and Master of Engineering (2 years) [18] which offers degrees Bachelor of Engineering (4 years) and Master of Engineering (2 years). Some other European universities offer 3 years long programs for Bachelor of Science such as universities in Denmark [19], Portugal [20], Germany, Estonia, Sweden [21];

- Asia: Asian universities usually offer a 4 year undergraduate program in mechatronics engineering. Universities in Turkey [22], Israel [17] Japan, Korea, Taiwan, China, Hong Kong [23], China [24], Thailand, Malaysia etc. [25] are offering Bachelor of Science degrees in Mechatronic Engineering;

- Australia: Universities in Australia also offer Bachelor of Science in Mechatronic Engineering which last 4 or 5 years $[26,27]$. Other universities in Australia offer dual degree option of Bachelor of Science and Bachelor of Engineering which lasts five years [28, 29];

- Africa: In Africa, Mechatronic Engineering Bachelor of Science (5 years) and Master of Science (2 years long) [30];

- Americas: In America, mechatronics was firstly introduced at U.S. universities which have electronic manufacturing technology laboratories and they were focused on electronic packaging and assembly, adaptive control, and intelligent manufacturing systems [12]. Bachelor of Science programs in mechatronic engineering and mechatronics engineering technology usually last 4 years $[31,32]$. In the U.S. students are receiving Bachelor of Science in Mechatronic Engineering or Mechatronic Engineering technology. In Canada, Bachelor of Engineering in Mechanical and Mechatronics Engineering program also lasts 4 years [33]. In Mexico, Bachelor of Science in Mechatronic Engineering programs last 4 years $[34,35]$.

Mechatronics study program at University of Novi Sad, with structured courses, was designed according to the industry needs in the regional workforce. The courses are divided in the following groups: core (general) courses, theoretically methodological, scientifically 
professional and professionally applicative courses. Basic study program (undergraduate) was structured based on a benchmarking study done by analysis of already existing three programs at other universities - TU Dresden, Germany [36]; TU Ilmenau [37], Germany and University of Waterloo [33], Canada.

The main ideas which guided Mechatronics study program curriculum development were based on four main dimensions (as shown in Fig. 1):

1. Content knowledge \& developed competencies designed as a response to the needs from an industry;

2. Stackable credentials in the area of mechatronics which are building up from the basic and more general to applied and more specific;

3. Different means of learning through: theory application, problem based learning, projects, semester papers, independent and teamwork problem solving techniques;

4. Student engagement through homework, research and industry based projects (not more than 30 hours per week according to the given state regulations).

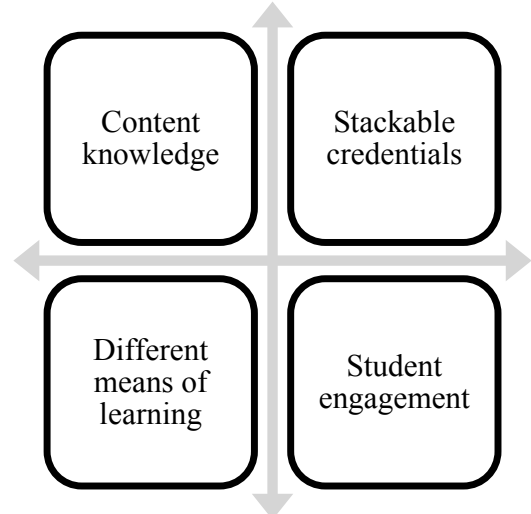

Figure 1 Four dimensions of curriculum development

\subsection{Undergraduate engineering program in mechatronics at the Faculty of Technical Sciences}

The undergraduate academic study program in Mechatronics lasts four years and there are two study groups: Mechatronics, robotics and automation, and Mechatronics in mechanization. The first three years are the same for both study groups and then students, according to their interests, choose one of the two study groups.

Table 1 Freshman year in program of mechatronic at the Faculty of Technical Sciences

\begin{tabular}{|c|l|c|c|c|}
\hline N. & \multicolumn{1}{|c|}{ Course Title } & Semester & ECTS \\
\hline 1 & Physics & Fall & & 5 \\
\hline 2 & Fundamentals of Product Development & Fall & & 6 \\
\hline 3 & Mathematics 1 & Fall & & 7 \\
\hline 4 & Fundamentals in Power Engineering & Fall & & 4 \\
\hline 5 & Fundamentals in Computing & Fall & & 4 \\
\hline 6 & Materials in Mech. Eng. 1 & Fall & & 4 \\
\hline 7 & Mathematics 2 & & Spring & 7 \\
\hline 8 & Fundamentals in Power Eng. 2 & & Spring & 5 \\
\hline 9 & Fundamentals in Programming 2 & & Spring & 5 \\
\hline 10 & Materials in Power Engineering 2 & & Spring & 4 \\
\hline 11 & Mechanics 1 - fundamentals 2 & & Spring & 7 \\
\hline 12 & Sociology in Engineering & & Spring & 2 \\
\hline \multicolumn{4}{|c|}{ Total number of ECTS credits: } & 60 \\
\hline
\end{tabular}

Courses offered at freshman year are given in Tab. 1, sophomore year in Tab. 2 junior year in Tab. 3 and Senior year in Tab. 4.

The group Mechatronics, robotics and automation is oriented toward implementation of mechatronics in automation and robotics in industrial and nonindustrial (e.g. home automation) systems. Other study group, Mechatronics in mechanization, is oriented towards the implementation of mechatronics components in a contemporary mechanization.

Undergraduate curriculum in Mechatronics includes approximately $15 \%$ of general, $20 \%$ of theoretically methodological, $35 \%$ of scientifically professional and 30 $\%$ of professionally applicative courses. Apart from this classification, the courses taught at these studies can be divided into the following groups: general engineering courses; electrical engineering courses; control engineering courses; mechanical engineering courses; computer sciences courses; programming and application of program packages (for CAD- Computer-aided design, SCADA -Supervisory Control and Data Acquisition, simulations, etc.) courses; and industry applied courses. In this way the students participate in hands-on activities, which test their previously acquired knowledge in the field of mechatronics and they are getting also a practical experience. A number of problems are solved in the laboratory with didactic equipment and equipment used in industrial applications $[3,38,39,40]$.

Table 2 Sophomore year in program of mechatronic at the Faculty of Technical Sciences

\begin{tabular}{|c|l|c|c|c|}
\hline N. & \multicolumn{1}{|c|}{ Course Title } & Semester & ECTS \\
\hline 13 & Mechanics 2 - general & Fall & & 7 \\
\hline 14 & Material Strength & Fall & & 4 \\
\hline 15 & Mathematics 3 & Fall & & 3 \\
\hline 16 & Mechanical Elements 1 & Fall & & 5 \\
\hline 17 & Introduction to Electronics 3 & Fall & & 5 \\
\hline 18 & Systems of Automated Management 4 & & Spring & 2 \\
\hline 19 & Programming and Program Languages 4 & & Spring & 4 \\
\hline 20 & Mechanical Elements 2 & & Spring & 5 \\
\hline 21 & Digital Electronics 4 & & Spring & 5 \\
\hline 22 & Measurements in Engineering & & Spring & 7 \\
\hline \multicolumn{3}{|c|}{ Total number of ECTS credits: } & 60 \\
\hline
\end{tabular}

Table 3 Junior year in program of mechatronic at the Faculty of Technical Sciences

\begin{tabular}{|c|l|c|c|c|}
\hline N. & \multicolumn{1}{|c|}{ Course Title } & Semester & ECTS \\
\hline 23 & Micro process Electronics & Fall & & 7 \\
\hline 24 & Modelling and System Simulation 1 & Fall & & 4 \\
\hline 25 & Automated Management 2 & Fall & & 3 \\
\hline 26 & Mechanics 3 & Fall & & 5 \\
\hline 27 & Analogue Electronics & Fall & & 5 \\
\hline 28 & Mechanics of Machines & & Spring & 2 \\
\hline 29 & Industrial Robotics & & Spring & 4 \\
\hline 30 & Impulse Electronics & & Spring & 8 \\
\hline 31 & Components of Technological & & Spring & 8 \\
\hline 32 & Applications of Sensors and Applicators & & Spring & 6 \\
\hline \multicolumn{3}{|c|}{ Total number of ECTS credits: } & 60 \\
\hline
\end{tabular}

In each study group students have core and elective courses. Elective courses account for $30 \%$ of overall ECTS credits in the program. Furthermore, students have also a possibility to take other courses from different program at the Faculty of Technical Sciences or any other University in the country or abroad. Number of students at undergraduate Mechatronics study program who were 
enrolled as the generation of 2011/12 was 70 freshmen, 38 sophomore, 33 juniors, and 31 seniors.

Table 4 Senior year in program of mechatronic at the Faculty of Technical Sciences

\begin{tabular}{|c|c|c|c|c|c|}
\hline $\mathrm{N}$ & \multicolumn{2}{|r|}{ Course Title } & \multicolumn{2}{|c|}{ Semester } & ETCS \\
\hline 33 & \multicolumn{2}{|c|}{ Mechatronics } & Fall & & 7 \\
\hline 34 & \multicolumn{2}{|c|}{ Elective course - a) or b) } & Fall & & 7 or 8 \\
\hline & a) & Working Process Automation & Fall & & 7 \\
\hline & b) & $\begin{array}{l}\text { Heating, Ventilation and Air } \\
\text { conditioning }\end{array}$ & Fall & & 8 \\
\hline 35 & \multicolumn{2}{|c|}{$\begin{array}{l}\text { Elective course - one of the c), d), e), f), } \\
\text { g), or h) }\end{array}$} & Fall & & 4 to 6 \\
\hline 36 & \multicolumn{2}{|c|}{$\begin{array}{l}\text { Elective course - one of the c), d), e), f), } \\
\text { g), or h) }\end{array}$} & Fall & & 4 to 6 \\
\hline 37 & \multicolumn{2}{|c|}{$\begin{array}{l}\text { Elective course - one of the c), d), e), f), } \\
\text { g), or h) }\end{array}$} & Fall & & 4 to 6 \\
\hline & c) & Technology of Handling Materials & Fall & & 6 \\
\hline & d) & Optimization Methods & Fall & & 4 \\
\hline & e) & $\begin{array}{l}\text { Programming and Application } \\
\text { PLCs }\end{array}$ & Fall & & 5 \\
\hline & f) & $\begin{array}{l}\text { Numeric Algorithms and Numeric } \\
\text { Software }\end{array}$ & Fall & & 4 \\
\hline & g) & $\begin{array}{l}\text { Artificial Intelligence in } \\
\text { Engineering }\end{array}$ & Fall & & 5 \\
\hline & h) & Automated and robotic Assembly & Fall & & 5 \\
\hline 38 & \multicolumn{2}{|c|}{$\begin{array}{l}\text { Systems for Surveillance and Process } \\
\text { Visualization }\end{array}$} & & Spring & 5 \\
\hline 39 & \multicolumn{2}{|c|}{ Elective course - one of the i), j), k), or l) } & & Spring & 5 \\
\hline 40 & \multicolumn{2}{|c|}{ Elective course - one of the i), j), k), or l) } & & Spring & 5 or 6 \\
\hline & i) & Intelligent Systems & & Spring & 5 \\
\hline & j) & Modelling and System Simulation & & Spring & 5 \\
\hline & k) & Project Management & & Spring & 5 \\
\hline & 1) & $\begin{array}{l}\text { Computer Integration of Production } \\
\text { System }\end{array}$ & & Spring & 6 \\
\hline 41 & \multicolumn{2}{|c|}{ Foreign Language (English or German) } & & Spring & 2 \\
\hline 42 & \multicolumn{2}{|c|}{ Professional Practice-BSc } & & Spring & 2 \\
\hline 43 & \multicolumn{2}{|c|}{ Bachelor Paper } & & Spring & 15 \\
\hline & & Tot & & credits: & $0 \div 69$ \\
\hline
\end{tabular}

\subsection{Graduate engineering program in mechatronics at the Faculty of Technical Sciences}

\subsubsection{Master in Mechatronics}

The curriculum for the graduate academic studies Master in Mechatronics is a continuation of the undergraduate academic study program in Mechatronics, founded in 2009. Previously, there was no distinction among the undergraduate academic study program and the master academic study program. At that time, Mechatronics program lasted for five years with no option for Bachelors. In 2009, an undergraduate academic study program and master academic study program were defined.

Graduate program, master level, in Mechatronics lasts for one year. There are two study groups, similar to an undergraduate academic study in Mechatronics: Mechatronics, robotics and automation and Mechatronics in mechanization. According to their interests and their prior knowledge, students enroll in one of the two study groups. Number of students at master mechatronics study program who enrolled as the generation of 2011/12 was 14.

This curriculum has $83,33 \%$ of total credits for elective courses. Courses have lectures and labs. An emphasis is placed on independent research. Modern didactic tools are used as a support to subject content. Students study about the current research trends in the field of mechatronics. Labs can be taught in a traditional, laboratory and computer setting. In addition, labs can be realized in an industry setting and other institutions. Assignments are emerged into scientific writing portion through their seminar papers, homework, project assignments, and semester and design projects. Another very important component of the Mechatronics curriculum is the professional practice. It is usually done at the scientific and research institutions, innovation incubators, and public institutions. The student gains a certain number of ECTS by passing each exam. Studies are considered complete when a student fulfils all obligations required in the study program and collects at least 60 ECTS (passes all the required courses, and defends the final work - master thesis).

Master thesis consists of theoretical and methodological preparation necessary for further in-depth understanding of the area of master thesis, and the production of the work. Some examples of research topics for Master theses are e.g. programming; automation (SCADA, programmable logic controllers - PLCs robotics, electro-pneumatic, electro-hydraulics); communications (Bluetooth technology, Wi-Fi, Global System for Mobile Communications - GSM, fieldbus); home automation; identification technologies (RFID, Bar code, biometrics). Similar topics are used for Bachelor senior design projects (done individually), but they are more industry and application based projects.

\subsubsection{Doctoral program in Mechatronics}

The curriculum for the graduate academic studies Doctor of Science - Mechatronics (Ph.D.) is a continuation of the master academic study program in Mechatronics, founded in 2005. It lasts for three years and it has 90 ECTS in courses, 30 ECTS for a prelim exam, and 60 ECTS for doctoral dissertation defence. The limitation for the maximum time allowed for the doctoral studies is that they cannot last longer than 10 years. Total number of students enrolled in 2012 was 15.

The qualifying exam serves as a first step for students to demonstrate that they have mastered the necessary theoretical knowledge in the scientific field of interest and that they qualify for committee to approve their dissertation research topic. Theoretical foundations are included in a written or oral exam, defined by area and its current issues. It has to be related to at least three completed courses from study program in the area of mechatronics.

Doctoral studies are organized through lectures, research study, research work, construction and doctoral dissertation defence. Student's research interests are profiled by selecting focused courses; and thus, contribute in-depth knowledge and understanding of areas of his or her doctoral dissertation. Mechatronics is organized in three semesters. There are seven required courses in the curriculum of doctoral study program. One of these courses is core course (Scientific Research Method) while all other courses are electives. Elective courses are selected from the group of proposed courses in a study program. They are valued with $56,11 \%$ of overall ECTS credits in the program. Furthermore, students have the opportunity to choose a number of courses from a set of 
courses at Doctoral Studies program at the Faculty of Technical Sciences, University of Novi Sad, or any other university in the country or abroad.

Research topics in this doctoral program include: mechatronics systems, automated systems, control systems, automatic identification technologies, wireless sensor networks, industrial and humanoid robotics, mobile technologies in automation systems, embedded systems, unmanned aerial vehicles, Internet of Things, etc.

\section{Assessment}

Every semester, student evaluations are collected. They are providing a constant valuable feedback which serves as a basis for curriculum improvement. These evaluations are collected for every course separately, but also for the whole mechatronics program and students' perceptions related to their overall level of satisfaction. Student evaluations are collected from 1995 at the Faculty of Technical Sciences. Student evaluations related to their satisfaction with the overall program in Mechatronics are collated from 2011. Data was collected from eight groups of students: freshman, sophomore, junior, senior, master (fifth year), and graduates with B.S., M.S. and dipl. ing. Master degrees.

Three main questions were included in this data analysis. The first two questions were qualitative and they included a Likert scale with six levels of student satisfaction: 5 (Not satisfied at all), 6 (Satisfied to an extent), 7 (Satisfied), 8 (Very satisfied), 9 (Extremely satisfied), 10 (Beyond my expectations). In addition, the third question was an open ended, qualitative question in which students could add any other comments which they thought was appropriate to explain better their opinions. The first question related to the student evaluations of the mechatronic program was: "Due to which extent are you satisfied with the facilities used for lectures, labs and research in your program?" The second question related to the student evaluations of the mechatronic program was: "Due to which extent are you satisfied with the curriculum of your program?"

Results from two consecutive years 2011/12 and 2012/13 are given in Tab. 5 and Tab. 6 and in Fig. 2 and 3 . In the qualitative portion, various students were raising concerns related to the level of difficulty of some courses. In addition, some students mentioned that more hands on labs and experience from the industry is needed, not only the theoretical knowledge.

According to the data collected, the main difference in the student opinions was in the group of students who are currently at their fifth year of study and are enrolled in a Master's program after they have completed their Bachelor's degree. In 2011/12 their level of satisfaction related to facilities is Master 7,7778, and in 2012/13 is 9,000 which are different by 1,2221. Similar to this, in a question which deals with the facilities in 2012/13, students who completed their Bachelor's degree rated facilities with the level of 7,5560. Based on this data, department is looking into more ways to find funding for more didactic equipment that can be used for lectures and labs. Based on this assessment, faculty organized different activities related to student and industry engagement.
Overall, level of student satisfaction was rated as very good if compared to other study programs at the university. This was especially important for faculty and staff since this program is one of the newest at our university.

Table 5 Average values for student satisfaction related to facilities and curriculum in the mechatronic Program in 2011/12

\begin{tabular}{|c|c|c|c|}
\hline Year & Facilities & Curriculum & $\begin{array}{c}\text { Number of } \\
\text { students }\end{array}$ \\
\hline Freshman & 9,0172 & 8,8276 & 58 \\
\hline Sophomore & 8,5897 & 8,8205 & 39 \\
\hline Junior & 8,6500 & 8,9000 & 20 \\
\hline Senior & 8,6176 & 8,5000 & 34 \\
\hline Master & 7,7778 & 8,1111 & 9 \\
\hline B.S. & 8,3333 & 8,8333 & 15 \\
\hline M.S. & 9,0000 & 9,0000 & 15 \\
\hline dipl. ing. & 8,3750 & 8,8750 & 24 \\
\hline
\end{tabular}

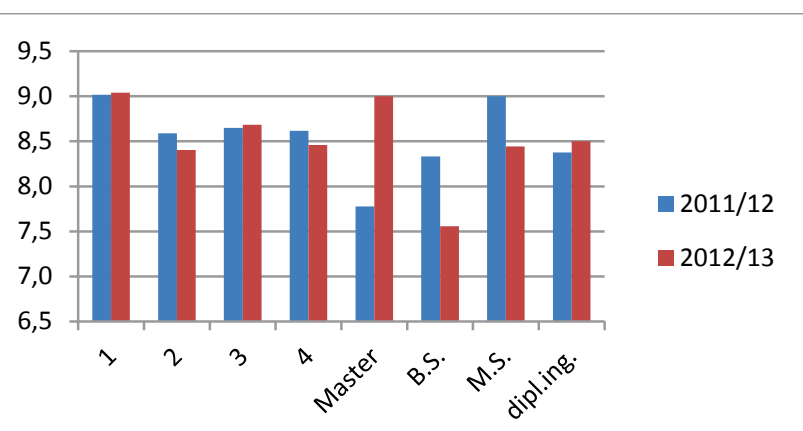

Figure 2 Student satisfaction related to the facilities used for lectures, labs and research

Table 6 Average values for student satisfaction related to facilities and curriculum in the mechatronic program in 2012/13

\begin{tabular}{|c|c|c|c|}
\hline Year & Facilities & Curriculum & Number of students \\
\hline Freshman & 9,0392 & 8,8627 & 51 \\
\hline Sophomore & 8,4043 & 8,4255 & 47 \\
\hline Junior & 8,6842 & 8,5789 & 38 \\
\hline Senior & 8,4600 & 8,6200 & 50 \\
\hline Master & 9,0000 & 8,8750 & 16 \\
\hline B.S. & 7,5560 & 8,3077 & 36 \\
\hline M.S. & 8,4444 & 8,5385 & 9 \\
\hline dipl. ing. & 8,5000 & 9,0000 & 24 \\
\hline
\end{tabular}

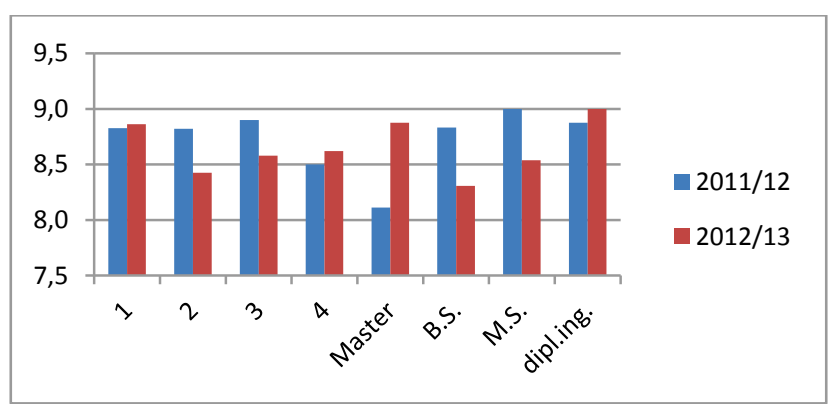

Figure 3 Student satisfaction related to the curriculum

\section{Conclusions}

Mechatronics education around the world has various levels such as: course level, education at the vocational high schools (predominantly in Europe and Asia), mechatronics certificates, Associate of Science degree, Bachelor of Science (U.S., Australia and U.K.) or Bachelor of Engineering (Europe and Asia), Master of Science degree or doctoral studies. 
Mechatronic education programs at the University of Novi Sad include all three academic levels, Bachelor's, Master's and Doctoral. There have been around 500 students so far enrolled in Mechatronic program since it initially started in 2002.

Initially, Bachelor's and Master's program were part of the same degree, and students did not have an option to finish up by receiving B.S. degree only. It used to be five years long program. So far, total of 78 students have received their M.S. in Mechatronics engineering degree in the integrated five year program. After the program was transformed according to the Bologna process (European accreditation education body), 79 students completed their Bachelor's degree and 28 students completed their Masters degrees. From 1999 until 2002, students were receiving degree in Industrial Engineering, with the specialization area in Mechatronics, Robotics and Automation in a five year long program. Before 1999, Mechatronics, Robotics and Automation were a specialization area with students receiving degree in Mechanical Engineering, also five years long, without Bachelor's degree.

Students who are getting into the Mechatronics program are the ones who usually complete high schools which are in the area of general education - heavily focused on math and science (science track), electrical engineering high school and mechanical engineering high school (similar to advanced placement pre-engineering classes in the U.S.). These students have to take an entrance exam (math and native language) to get qualified to enrol in one of these high school programs.

In addition, they are required to take an entrance exam to get enrolled into Mechatronics program. This entrance exam is the same one as the students who want to get enrolled into Electrical and Computer Engineering are taking at the University of Novi Sad.

As a part of the engineering technical high school programs, there are specialization areas in mechatronics as part of mechanical or electrical programs. These students are receiving degrees of licensed electrician or licensed mechanical technician. Although some technical high schools are offering a degree track of mechatronics technician (a four year program), in the Republic of Serbia still there is no such a thing as licensed mechatronics technician yet.

Industry has recognized the need for this kind of engineering occupation area. Graduates from these programs are getting hired by a range of different industries which have electromechanical products or they work for software development companies as programmers and software developers since they have advanced programming skills. Curriculum standards are defined based on the industry needs of the country and further modified based on data retrieved from Industrial Advisory Boards and the inputs from Department of Labor (Department of National Employment Services). There are not so many graduates who stay unemployed in a year after the graduation.

Some students chose to work in one of the global companies or continue their graduate education in the international setting by leaving the country. Their degrees are in compliance with the education qualifications standards set by the Bologna Process, which is European certification body, similar to the U.S. ABET accreditation process. Hence, they can be employed and admitted to graduate programs with no problem. Graduates from the Mechatronics program are highly sought by the advanced manufacturing industry since they are educated basically to understand the language of three diverse engineering and science areas: mechanical engineering, electrical and computer engineering and computer science.

Based on the industry needs in the region, it is apparent that more mechatronics programs are needed at departments other than the University of Novi Sad. Currently this is the only university in the country and the region which has three academic levels of Mechatronic Education: Bachelor's, Master's and Doctoral. Advanced manufacturing sectors are having more jobs open in the areas which need skills related to design and application of equipment which is in essence mechatronics. Hence, the needs for this occupation area are rapidly growing.

\section{References}

[1] Flaxer, E.; Becker, I.; Fisherman, B. An alternative approach in mechatronics curricular development at AFEKA - Tel-Aviv Academic College of Engineering and at Tel-Aviv University. // International Journal of Mechanical Engineering Education. 36, (2008), pp. 266282. DOI: $10.7227 / / J M E E .36 .3 .10$

[2] See, A. Challenging computer-based projects for a Mechatronics course: Teaching and learning through projects employing virtual instrumentation. // Computer Applications in Engineering Education. 14, (2006), pp. 222242. DOI: 10.1002/cae.20083

[3] Skrinjar, D.; Baranovski, I.; Dragicevic, D.; Stankovski, S.; Ostojic, G.; Miladinovic, L. Development of a Didactic Set of Pneumatics and Servo Pneumatics in Engineering Education. // Transactions of FAMENA. 36, (2012), pp. 6978.

[4] Herakovic, N.; Simic, M.; Trdic, F.; Skvarc, J. A machinevision system for automated quality control of welded rings. // Machine Vision and Applications. 22, 6(2011), pp. 967-981. DOI: $10.1007 / \mathrm{s} 00138-010-0293-9$

[5] Komoto, H.; Tomiyama, T. A framework for computeraided conceptual design and its application to system architecting of mechatronics products. // Computer-Aided Design. 44, 12(2012), pp. 931-946. DOl: 10.1016/j.cad.2012.02.004

[6] Jovanovic, V. Examining the Extent of Environmental Compliance Requirements on Mechatronic Products and Their Implementation through Product Lifecycle Management. // ProQuest LLC, (2010).

[7] Gausemeier, J.; Dumitrescu, R.; Kahl, S.; Nordsiek, D. Integrative development of product and production system for mechatronic products. // Robotics and ComputerIntegrated Manufacturing. 27, 8(2011), pp. 772-778. DOI: 10.1016/j.rcim.2011.02.005

[8] Brown, N. J.; Brown, O. T. Mechatronics "a graduate perspective". // Mechatronics. 12, 3(2002), pp. 159-167. DOI: 10.1016/S0957-4158(01)00056-3

[9] Vukelic, D.; Ostojic, G.; Stankovski, S.; Lazarevic, M.; Tadic, B.; Hodolic, J.; Simeunovic, N. Machining fixture assembly/disassembly in RFID environment. // Assembly Automation. 31, 1(2011), pp. 62-68. DOI: 10.1108/01445151111104182

[10] Singhose, W.; Vaughan, J.; Mayor, R. Use of design competitions in mechatronics education. // ICM 2009. Proceedings of IEEE International Conference on Mechatronics, 2009, pp. 1-6. 
[11] Lyshevski, S. E. Mechatronic curriculum - retrospect and prospect. // Mechatronics. 12, 3(2002), pp. 195-205. DOI: 10.1016/S0957-4158(01)00060-5

[12] Hirschfeld, R. A.; Liao, T. W.; Keys, L. K. Mechatronics education developments in the United States: The perspective from Louisiana State University. // Mechatronics. 4, 4(1994), pp. 233-246. DOI: 10.1016/09574158(94)90002-7

[13] Mehmet, A.; Hakan, Ç.; Taner, A. A New Trend in Vocational Education: Mechatronics Program and the Preference Factors. // Technics Technologies Education Management. 7, (2012), pp. 638-647.

[14] Acar, M.; Parkin, R. M. Engineering education for mechatronics. // IEEE Transactions on Industrial Electronics. 43, (1996), pp. 106-112. DOI: 10.1109/41.481414

[15] Hegde, G. S. Mechatronics. Sudbury, Mass.: Jones and Bartlett Publishers, 2010

[16] Europe Commision. European Credit Transfer and Accumulation System (ECTS). 2013. URL: $\mathrm{http}$ :/ec.europa.eu/education/lifelong-learningpolicy/ects_en.htm (5.1.2014).

[17] Flaxer, E.; Becker, I.; Fisherman, B. An alternative approach in mechatronics curricular development at AFEKA - Tel-Aviv Academic College of Engineering and at Tel-Aviv University. // International Journal of Mechanical Engineering Education. 36, (2008), pp. 266282. DOI: $10.7227 / / J M E E .36 .3 .10$

[18] Dublin City University. School of Electronic Engineering B. Eng. and M. Eng in Mechatronic Engineering Bachelor Honours and Masters Degree. 2012. URL: http://www.dcu.ie/prospective/deginfo.php?classname=ME (28.10.2014).

[19] University of Southern Denmark. Mechatronics (Engineering). 2012. URL: http://studyindenmark.dk/studyprogrammes/programmes-in-english/mechatronicsengineering (28.10.2014)

[20] Lima, M.; Gomes, M. P.; Putnik, G.; Silva, S.; Monteiro, J.; Couto, C. Mechatronics education at the University of Minho: a summary of the present; perspectives for the future. // Mechatronics. 12, (2002), pp. 295-302. DOl: 10.1016/S0957-4158(01)00069-1

[21] Grimheden, M.; Hanson, M. Mechatronics - the evolution of an academic discipline in engineering education. // Mechatronics. 15, (2005), pp. 179-192. DOI 10.1016/j.mechatronics.2004.07.010

[22] Akpinar, B. Mechatronics education in Turkey. // Mechatronics. 16, (2006), pp. 185-192. DOI: 10.1016/j.mechatronics.2005.11.001

[23] Acar M.; Parkin, R. M. Engineering education for mechatronics. // IEEE Transactions on Industrial Electronics. 43, (1996), pp. 106-112. DOI: 10.1109/41.481414

[24] Wang, Y.; Schwarz, B.; Pan, Y.; Chen, B.; Wiedmann, H.; Xie, C. Mechatronics education at CDHAW of Tongji University: Structure, orientation and curriculum. // Mechatronics. 18, (2008), pp. 172-177. DOI 10.1016/j.mechatronics.2007.11.001

[25] Tan, K. K.; Lee, T. H.; Dou, H. F.; Lim, S. Y. Various developments in mechatronics in Asia. // Mechatronics. 8 (1998), pp. 777-791. DOI: 10.1016/S0957-4158(98)00022-1

[26] Monash University. Bachelor of Mechatronics Engineering and Bachelor of Science. 2013. URL: http://www.monash.edu.au/study/coursefinder/course/3282 (29.10.2014).

[27] Swinburne University of Technology. Bachelor of Engineering (Robotics and Mechatronics). 2012. URL: http://www.future.swinburne.edu.au/courses/Bachelor-ofEngineering-(Robotics-and-Mechatronics)R050/local\#details (29.10.2014)

[28] Macquarie University. Bachelor of Engineering with the degree of Bachelor of Science with a major in Mechatronic
Engineering. 2012. URL: http://courses.mq.edu.au/ undergraduate/doubledegree/bachelor-of-engineering-withthe-degree-of-bachelor-of-science/major-in-mechatronicengineering (29.10.2014).

[29] Queensland University of Technology. Bachelor of Engineering (Mechatronics). 2012. URL: https://www.qut.edu.au/science-engineering/courses-andstudy/undergraduate-courses (30.10.2014).

[30] Jomo Kenyatta University of Agriculture and Technology. BSc. Mechatronic Engineering. 2012. URL: http://www.jkuat.ac.ke/departments/mechatronics/?page_id $=739(30.10 .2014)$.

[31] Southern Polytechnic State University. Mechatronics Engineering. 2012. URL: http://www.spsu.edu/ mechatronics/index.htm (30.10.2014).

[32] Central Connecticut State University. Robotics and Mechatronics Engineering Technology 2012. URL: http://web.ccsu.edu/set/academics/programs/manufacturing Construction/robotics.asp (30.10.2014).

[33] University of Waterloo. Mechatronics Engineering. 2012. URL: $\quad$ https://uwaterloo.ca/mechanical-mechatronicsengineering/future-undergraduate-students/mechatronicsengineering (31.10.2014)

[34] Technological University of Mixteca. Bachelor of Science in Mechatronic Engineering. 2012. URL: http://www.utm.mx/ing_mecatronica_eng.html (31.10.2014)

[35] Technologico de Monterrey. BEM - Bachelor in Mechatronics Engineering. 2011. URL: http://www.itesm.edu/wps/wcm/connect/migration/CSF2/S anta $+\mathrm{Fe} /$ Programas + educativos/Carreras + profesionales/Car reras+profesionales+version+internacional/BEM++Bachelor+in+Mechatronics+Engineering/ (31.10.2014).

[36] Technische Universitat Dresden. Mechatronik - Das Dresdner Studiengangsmodell. 2013. URL: http://www.et.tu-dresden.de/mechatronik-diplom/ET.html (31.10.2014)

[37] Technische Universitat Ilmenau. Bachelor Mechatronik 2008. URL: http://www.tu-ilmenau.de/modultafeln/ Mechatronik (31.10.2014).

[38] Ostojic, G.; Stankovski, S.; Tarjan, L.; Senk, I. Jovanovic, V. Development and Implementation of Didactic Sets in Mechatronics and Industrial Engineering Courses // International Journal of Engineering Education, 26, (2010), pp. 2-8.

[39] Stankovski, S.; Tarjan, L.; Skrinjar, D.; Ostojic, G.; Senk, I. Using a Didactic Manipulator in Mechatronics and Industrial Engineering Courses. // IEEE Transactions on Education. 53, (2010), pp. 572-579. DOI: 10.1109/TE.2009.2036002

[40] Senk I.; Ostojic G.; Jovanovic V.; Tarjan L.; Stankovski S. Experiences in developing labs for a supervisory control and data acquisition course for undergraduate Mechatronics education. // Computer Applications in Engineering Education. 23, 1(2015), pp. 54-62. DOI: 10.1002/cae.21578

\section{Authors' addresses}

Dr. Sc. Gordana Ostojic

University of Novi Sad,

Faculty of Technical Sciences

Trg Dositeja Obradovića 6,

21000 Novi Sad, Serbia

E-mail: goca@uns.ac.rs

Dr. Sc. Vukica Jovanovic

Old Dominion University,

Mechanical Engineering Technology,

Frank Batten College of Engineering and Technology,

Norfolk, VA 23529, USA

E-mail: v2jovano@odu.edu 
Dr. Sc. Drazan Kozak

Josip Juraj Strossmayer University of Osijek, Mechanical Engineering Faculty,

Trg Ivane Brlić Mažuranić 2,

HR-35000 Slavonski Brod, Croatia

E-mail:dkozak@sfsb.hr

\section{Dr. Sc. Zeljko Ivandic}

Josip JurajStrossmayerUniversityof Osijek,

MechanicalEngineeringFaculty,

Trg Ivane BrlićMažuranić 2

HR-35000 Slavonski Brod, Croatia

E-mail: zivandic@sfsb.hr

Dr. Sc. Stevan Stankovski

University of Novi Sad,

Faculty of Technical Sciences

Trg Dositeja Obradovića 6 ,

21000 Novi Sad, Serbia

E-mail: stevan@uns.ac.rs 